\title{
FULL COST ACCOUNTING ON EXISTING AND FUTURE MUNICIPAL SOLID WASTE MANAGEMENT FACILITIES IN GREECE
}

\author{
KOMILIS D. ${ }^{1}, *$ \\ LIOGKAS V. ${ }^{2}$
}

\author{
${ }^{1}$ Laboratory of Solid and Hazardous Wastes \\ Dept. of Environmental Engineering \\ Democritus University of Thrace, Xanthi, Greece \\ ${ }^{2}$ MOU S.A. Technical Support Unit of Solid Waste and Wastewater \\ Projects for the Hellenic Ministry of the Environment
}

Received: $14 / 02 / 2014$

Accepted: 07/10/2014

Available online: $17 / 10 / 2014$

*to whom all correspondence should be addressed: e-mail: dkomilis@env.duth.gr

\section{ABSTRACT}

In this work, we performed a detailed full cost accounting for 7 types of existing and planned municipal solid waste management facilities (sanitary landfills, anaerobic digestion, biodrying, incineration, aerobic mechanical and biological, material recovery and waste transfer stations) in Greece. We used investment costs (IC), operating costs (OC) and future (restoration) costs (FC) to calculate the actual total unit cost $(€ / t)$ of the above types of facilities in 2012 prices. Mathematical cost functions were developed to describe the total cost $(€ / t)$ as a function of the MSW input rate $(t / y)$. Actual data from several operating facilities in Greece were used, as well as estimated costs from facilities that are planned or are under construction in Greece. Results showed that the sanitary landfills follow the economy of scale with an average total unit cost of $€ 45 / \mathrm{t}$. The unit cost of the planned anaerobic digestion facilities ranged from $€ 50$ to $€ 104 / t$. The biodrying facilities' unit cost ranged from $€ 48$ to $€ 138 / t$, whilst the sole MSW incineration facility was found to have a unit cost of $€ 115 / t$. Aerobic MBT facilities did not follow the economy of scale. The average total unit cost from $23 \mathrm{MRFs}$ was $€ 32 / \mathrm{t}$. The depreciated investment cost of 18 waste transfer stations (WTS) ranged from $€ 0.5 / \mathrm{t}$ to $€ 28 / \mathrm{t}$.

Keywords: depreciation, full cost accounting, municipal solid waste, operating cost, total unit cost

\section{Introduction}

Total cost is a key parameter when it is to design municipal solid waste management systems. Often, there is confusion in the literature with regard to the unit costs of MSW management facilities. For example, it is not always clear whether the investment cost has been included in total cost calculations, and if yes, what assumptions have been made to calculate it (e.g. depreciation rate, depreciation interest rate). As a result, it is hard to compare unit costs of MSW management facilities that have been reported by different researchers. Up to date, there is very limited information on the actual total cost of municipal solid waste (MSW) management in Greece. Total cost (TC), as defined in this work, was assumed to comprise the investment, the operating and the closure and post-closure (future) costs. The process of calculating and expressing the total (unit) cost of a facility in $€ / t$ is often called "full cost accounting (FCA)" (USEPA, 1997). Other costs, such as environmental and social costs, may be included in the TC (USEPA, 1997) but this was beyond the scope of this work.

During the past decade, several MSW management facilities (MSWMF) were constructed and operated in Greece. Currently in Greece, there are 75 operating sanitary landfills, 31 material recovery facilities (MRF), 2 biodrying facilities, 2 aerobic mechanical and biological pretreatment facilities (MBT) and

Komilis D. and Liogkas V. (2014), Full cost accounting on existing and future municipal solid waste management facilities in Greece, Global NEST Journal, 16(4), 787-796. 
approximately 59 waste transfer stations (WTS). In addition, 27 MSW pretreatment facilities, 12 MRFs and around 80 WTS are planned to be constructed in the future.

This work aimed to perform a FCA on 7 types of municipal solid waste management facilities in Greece, namely i) sanitary landfills, ii) anaerobic digestion units, iii) biodrying units, iv) incineration units, v) aerobic mechanical and biological units, vi) material recovery facilities, and vii) waste transfer stations. Actual data were obtained for existing facilities, whilst cost estimates were used for planned facilities using formally approved feasibility studies. An additional goal was to calculate regression cost functions to describe cost (i.e. investment cost, in $€$, and total unit cost, in $€ / t$ ) as a function of the waste input rate into the facility (t/y). Therefore, the economy of scale was examined for all 7 types of MSW facilities. The derived cost functions were compared to the approximate cost functions for similar MSW European management facilities (Tsilemou and Panagiotakopoulos, 2006).

\section{Methodology and financial equations}

\subsection{Total cost calculations of new facilities}

The total unit cost $(€ / t)$ of new facilities was calculated by accounting for the investment cost (IC) and the operating cost (OC). The equations to calculate total cost (TC) for a planned (new) facility were:

$\mathrm{TC}=(\mathrm{IC} * \mathrm{CRF}+\mathrm{OC}): \mathrm{MSW}$

$C R F=\frac{i^{*}(1+i)^{n}}{(1+i)^{n}-1}$

\begin{tabular}{ll}
\hline TC: & total unit cost of the facility $(€ / \mathrm{t})$, \\
\hline IC: & investment cost $(€)$, that did not include land acquisition costs, \\
\hline OC: & $\begin{array}{l}\text { operating cost }(€ / \mathrm{y}) ; \text { OC was based on estimates of operating cost reported in technical } \\
\text { studies, }\end{array}$ \\
\hline $\mathrm{MSW}:$ & MSW input rate into the facility (t/y), \\
\hline $\mathrm{CRF}:$ & capital recovery factor, \\
\hline $\mathrm{i}:$ & $\begin{array}{l}\text { annual discount (depreciation) interest rate (a constant } 6 \% \text { annual rate was used as a } \\
\text { default value), }\end{array}$ \\
\hline $\mathrm{n}:$ & $\begin{array}{l}\text { design life of a new (future) facility (a } 20 \text { year default value was used for all planned } \\
\text { facilities). }\end{array}$ \\
\hline
\end{tabular}

The current analysis included new (planned) anaerobic digestion, incineration, biodrying, aerobic MBT and WTS units.

\subsection{Total unit cost calculation of existing facilities}

The total unit cost of the existing facilities (landfills, biodrying, MBT units and MRF) accounted for the investment cost, the operating cost for the remaining design life of the facility and, in the case of the landfills, of the future restoration-monitoring cost (FC). The following equations were used in order to do that:

$$
\begin{aligned}
& k_{p}=I C_{p} * \frac{i *(1+i)^{n}}{(1+i)^{n}-1} \\
& I C_{p f}=k_{p} * \frac{(1+i)^{2012-Y R_{c}-1}}{i *(1+i)^{2012-Y R_{c}}} \\
& I C_{R}=I C_{p}-I C_{p f} \\
& I C_{R 2012}=I C_{R} * \frac{C P I_{2012}}{C P I_{Y R C}}
\end{aligned}
$$




$$
\begin{aligned}
& k_{F}=I C_{R 2012} * \frac{i *(1+i)^{n_{r}}}{(1+i)^{n_{r}}-1} \\
& T C_{F}=\left(k_{F}+O C * \frac{n_{r}}{20}+F C: M S W\right.
\end{aligned}
$$

\begin{tabular}{|c|c|}
\hline $\mathrm{i}:$ & $\begin{array}{l}\text { as previously defined; this is taken constant since the year of the construction of the facility } \\
\text { (default 6\% per year); }\end{array}$ \\
\hline $\mathrm{k}_{\mathrm{p}}:$ & $\begin{array}{l}\text { past annual uniform payments as calculated using the initial design life } n \text { of the facility and } \\
\text { the initial investment cost during the year of the construction of the facility }(€ / y) \text {; }\end{array}$ \\
\hline $\mathrm{n}:$ & design life of the facility (years); \\
\hline $\mathrm{IC}_{\mathrm{p}}$ : & investment cost of the facility during the year of its construction $(€)$; \\
\hline$I C_{p f}:$ & investment cost that has been paid off by year 2012 (year of analysis); \\
\hline $\mathrm{YR}_{\mathrm{C}}$ : & year of construction of the facility; \\
\hline $\mathrm{IC}_{\mathrm{R}}:$ & $\begin{array}{l}\text { remaining investment cost that is to be depreciated during the remaining design life of the } \\
\text { facility }(€) \text {; }\end{array}$ \\
\hline$I C_{R 2012:}$ & present worth (in 2012 prices) of the remaining investment cost $(€) ;$ \\
\hline $\mathrm{CPI}_{\mathrm{i}}:$ & consumer price index for year i (e.g. $\mathrm{CPI}_{2012}$ refers to year 2012); \\
\hline $\mathrm{k}_{\mathrm{F}}:$ & $\begin{array}{l}\text { future uniform annual payments required to pay off the remaining investment cost of the } \\
\text { facility }(€ / y) \text {; }\end{array}$ \\
\hline $\mathrm{n}_{\mathrm{r}}:$ & $\begin{array}{l}\text { remaining design life of facility beyond year } 2012(y) \text {; if this is calculated to be } 0 \text { or a } \\
\text { negative number, then the investment cost has been fully depreciated by year } 2012 \text { and } k_{F} \\
\text { equals } 0 \text {; }\end{array}$ \\
\hline OC: & $\begin{array}{l}\text { operating cost }(€ / y) \text {; OC was based on typical operating costs, which were converted to year } \\
\text { 2012. These operating costs are valid for the remaining design life of the facility. If the } \\
\text { design life of the facility has been exceeded }\left(n_{r} \leq 0\right) \text {, then the operating costs were taken } \\
\text { equal to } 0 \text {. }\end{array}$ \\
\hline FC: & $\begin{array}{l}\text { future or back-end costs }(€ / y) \text {; this cost includes the final capping and monitoring cost (in } \\
\left.€ / \mathrm{m}^{2}\right) \text { for a } 30 \text {-year monitoring period. The future cost is calculated according to chapter } 2.3 \text {, }\end{array}$ \\
\hline $\mathrm{TC}_{\mathrm{F}}:$ & total cost of facility $(€ / t)$ over its remaining design life; \\
\hline MSW: & actual flow of MSW into the facility (t/y). \\
\hline
\end{tabular}
Other parameters as previously defined.

\subsection{Future landfill costs}

The future (or back-end) costs refer only to the landfills. Landfill closure costs were determined by the area of the landfill and typical capping and post-closure monitoring cost coefficients. Based on unpublished data (personal communication with several Hellenic solid waste management regional associations), final landfill cover costs in Greece seem to range from $€ 20-€ 25 / \mathrm{m}^{2}$, whilst post-closure monitoring costs range from $€ 5-€ 10 / \mathrm{m}^{2}$ (over a 30-year period) The former capital costs were both amortized over 30 years, which is the typical monitoring period of a landfill in Europe, using equation (9):

$F C=\operatorname{Cap} \frac{i(1+i)^{n_{m}}}{(1+i)^{n_{m}}-1}$

\begin{tabular}{ll}
\hline FC: & annual future cost payments depreciated over a period of 30 years $(€ / \mathrm{y})$, \\
\hline Cap: & $\begin{array}{l}\text { final capping and monitoring cost (calculated by the area of the landfill and a default } \\
\left.\text { coefficient of } € 30 / \mathrm{m}^{2}\right),\end{array}$ \\
\hline $\mathrm{i}:$ & annual depreciation rate (default of $6 \%$ per year), \\
\hline $\mathrm{n}_{\mathrm{m}}:$ & landfill monitoring period (30 years), \\
\hline
\end{tabular}


The status and characteristics of the operating and planned MSW management facilities used in this work are included in Table 1.

Table 1. Status of the MSW management facilities used in this work

\begin{tabular}{|c|c|c|c|c|c|}
\hline Type of facility & Status & $\begin{array}{l}\text { Number of } \\
\text { units used in } \\
\text { the work }\end{array}$ & $\begin{array}{c}\text { Year of } \\
\text { construction }\end{array}$ & $\begin{array}{l}\text { Design } \\
\text { lives }(y)\end{array}$ & $\begin{array}{c}\text { Range of MSW input } \\
\text { rates } \\
\left(10^{3} \mathrm{t} / \mathrm{y}\right)\end{array}$ \\
\hline Sanitary landfills & Operating & 50 & $1993-2011$ & 5 to 28 & 0.045 to 1931 \\
\hline $\begin{array}{c}\text { Anaerobic digestion } \\
\text { facilities }\end{array}$ & Planned & 5 & & 20 & $\begin{array}{c}65,67,128,128 \\
300\end{array}$ \\
\hline \multirow{2}{*}{ Biodrying facilities } & Operating & 2 & 2011 & 18 & 25,75 \\
\hline & Planned & 3 & & 20 & $130,450,700$ \\
\hline Incineration & Planned & 1 & & 20 & 450 \\
\hline \multirow{2}{*}{$\begin{array}{l}\text { Aerobic MBT } \\
\text { facilities }\end{array}$} & Operating & 3 & $\begin{array}{c}\text { 1997-2002, } \\
\text { 2005-to date }\end{array}$ & 13,15 & $19,100,220$ \\
\hline & Planned & 5 & & 20 & 13 to 400 \\
\hline \multirow{2}{*}{$\begin{array}{c}\text { Waste Transfer } \\
\text { Stations }\end{array}$} & Operating & 2 & 2008 & 20 & $10.5,82$ \\
\hline & Planned & 16 & & & 0.8 to 98 \\
\hline MRFs & Operating & 23 & $1999-2012$ & 20 & 3.3 to 51.6 \\
\hline
\end{tabular}

All costs were converted to 2012 prices using the appropriate consumer price indexes (CPI) for Greece. The cost figures mentioned in Tsilemou and Panagiotakopoulos (2006), which were all in 2003 prices, were also converted to 2012 prices using the Hellenic CPIs for years 2012 and 2003. The Tsilemou and Panagiotakopoulos (2006) equations will be herein referred to as the TSPN equations and have been included in all figures to allow comparisons with the cost functions derived in this work.

\section{Results and discussion}

\subsection{Existing sanitary landfills}

Figure 1 shows the IC and the total unit cost of 50 operating sanitary landfills in Greece. The areas of all 50 landfills used in this work ranged from 1200 to $355,000 \mathrm{~m}^{2}$. According to Figure $1 \mathrm{a}$, only one cost outlier existed (i.e. the sanitary landfill of Chanea). In addition, there appears to be a very good agreement with the TSPN equation for sanitary landfills with MSW inlet rates lower than 60,000 t/y. For inlet rates greater than $60,000 \mathrm{t} / \mathrm{y}$, the TSPN equation overestimates the landfill investment costs. Note that Figure 1 does not illustrate the Attica landfill cost (yet this cost is included in the regression equation) which has an actual MSW inlet rate equal to 1,930,000 t/y. Operating costs were available for 31 landfills; however, the total unit costs are shown for all 50 landfills in Figure 1.

The total unit costs ranged from $€ 0.4 / t$ to $€ 331 / t$. The average total unit cost of all was $€ 45 / t$. Results are higher than the total unit cost estimates of the European Union for Hellenic landfills (€6/t) (Arcadis and Eunomia, 2009, pp. 50). Figure $1 \mathrm{~b}$ shows that an economy of scale exists in the case of Hellenic sanitary landfills. The depreciated investment costs (not shown in Figure 1) ranged from €0 (for existing landfills operating beyond their design lives) to $€ 258 / t$ for an existing small landfill in a remote Hellenic island (Agathonissi) with a MSW input rate at $45 \mathrm{t} / \mathrm{y}$. 
(a)

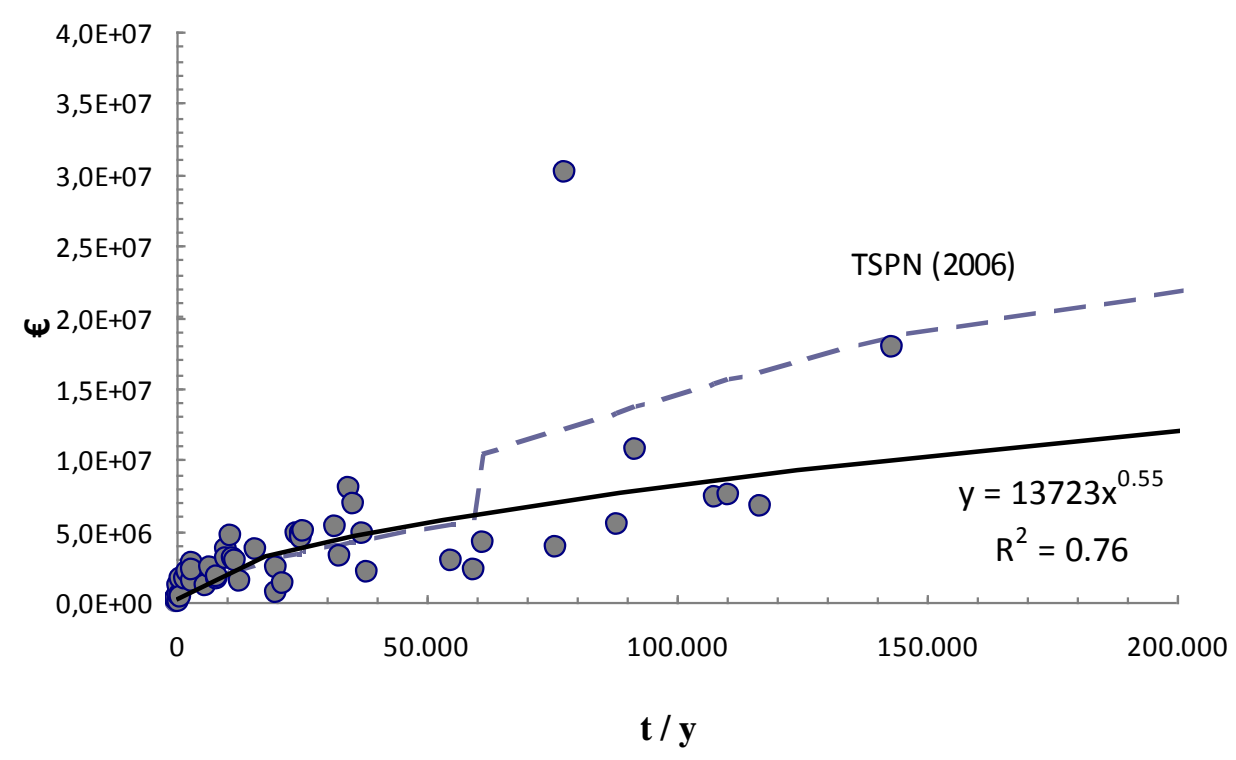

(b)

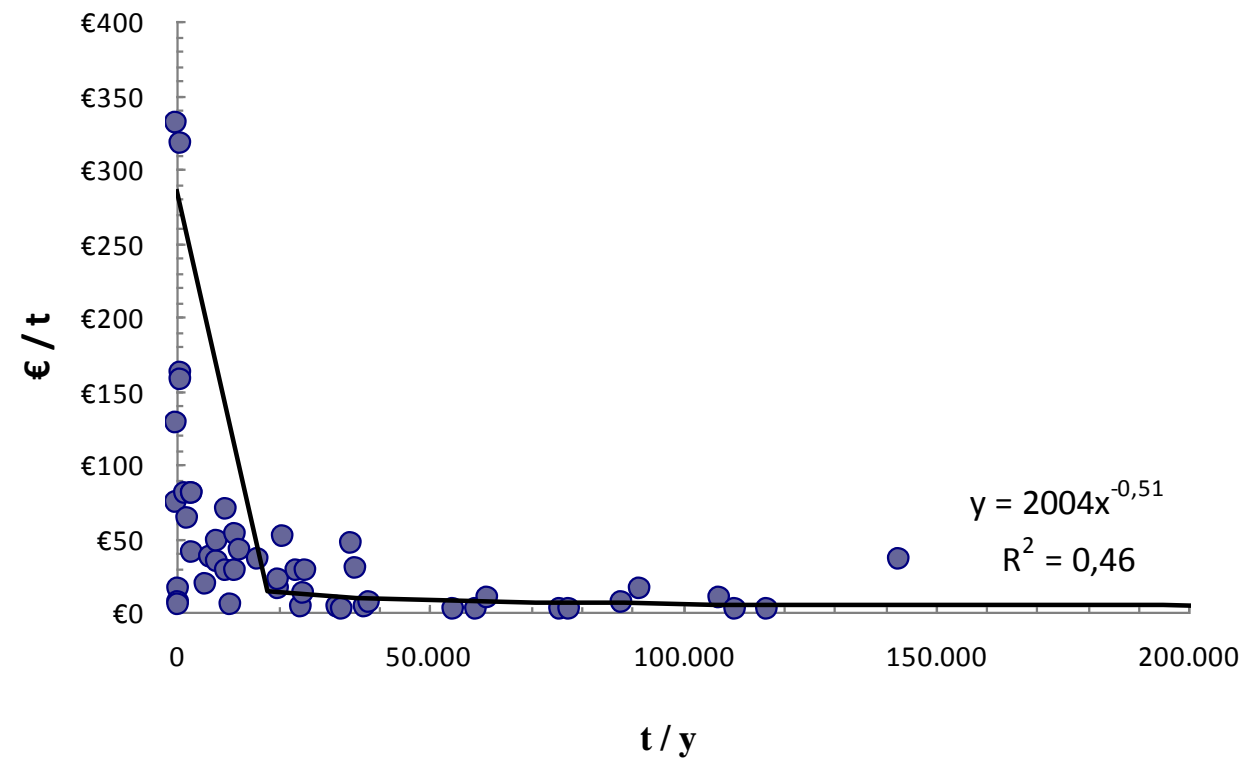

Figure 1. Cost functions for 50 existing sanitary landfills in Greece. (a): investment cost, (b): total unit cost. The Attica landfill, with an inlet waste rate of 1,930,000 t/y, is not shown in the figures; yet, its cost has been accounted for in the regression equations. All costs in 2012 prices

\subsection{Anaerobic digestion facilities}

There are plans to construct 5 MSW anaerobic digestion (ANB) facilities in Greece. Available operating cost data existed for 4 out of the 5 facilities. The financial data are depicted in Figure 2 . Note that the TSPN equation drawn on Figure 2 is valid only for MSW inlet rates less than 100,000 t/y. Actually, the TSPN equation seems to be in good agreement with the total cost of anaerobic facilities calculated in this work.

Despite the relatively small number of data points (4), an economy of scale seems to exist for the few planned anaerobic digestion facilities in Greece. Total cost ranges from $€ 50 / t$ to $€ 104 / t$. The latter unit cost is the same for 2 identical anaerobic digestion facilities in the Athens area. 
(a)

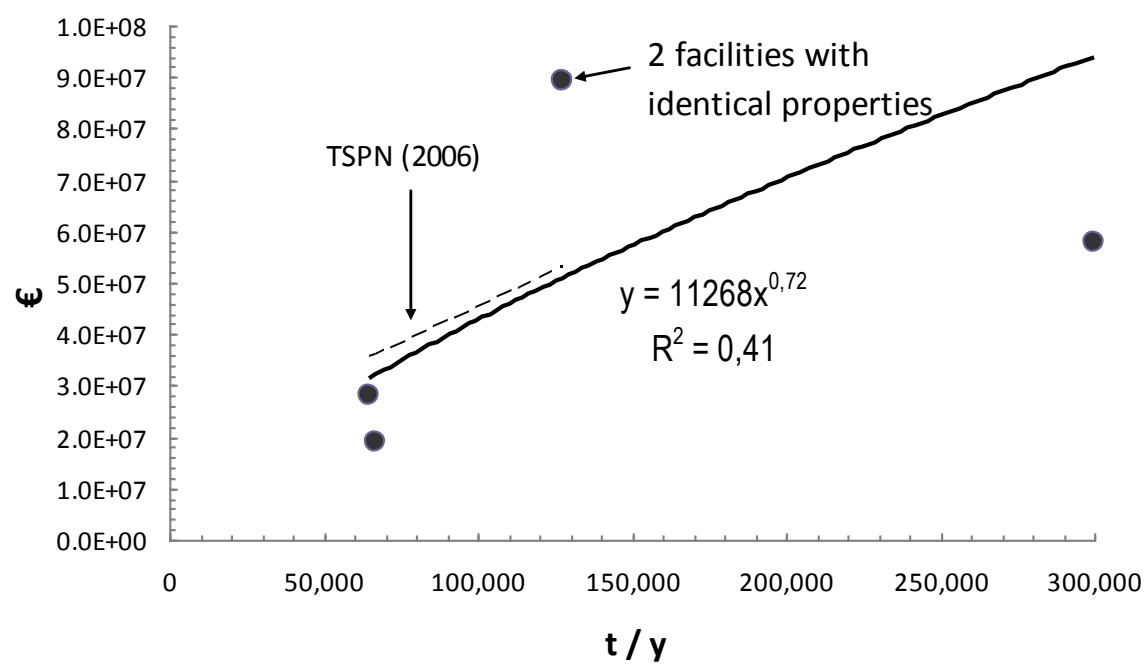

(b)

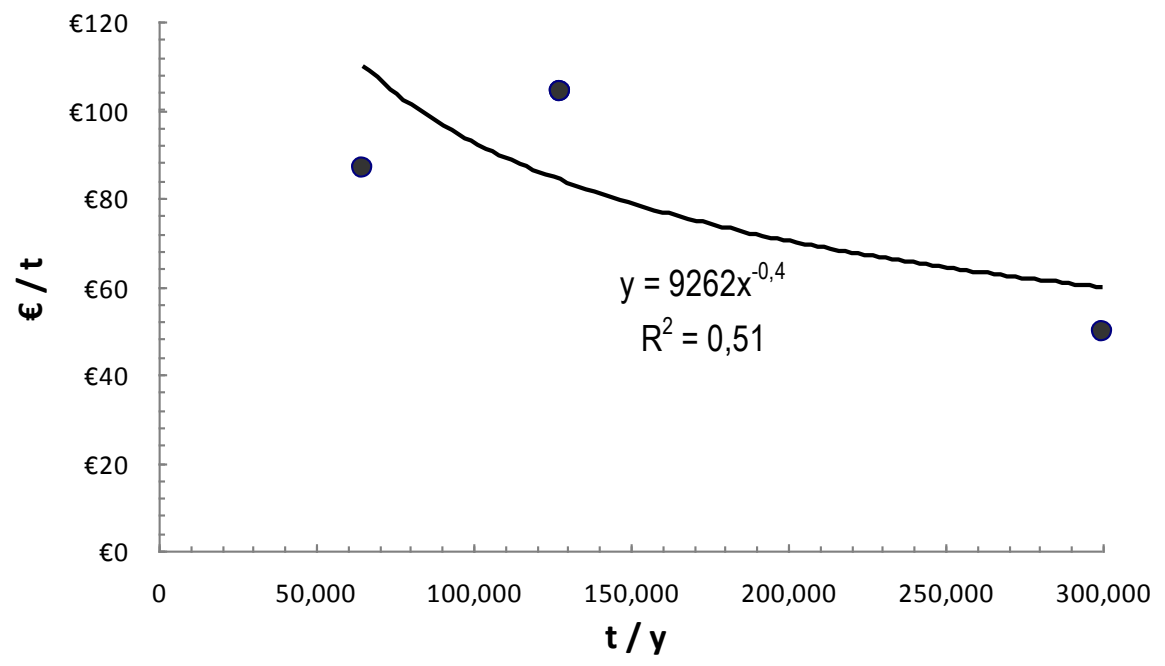

Figure 2. Cost functions for the planned anaerobic digestion facilities in Greece; (a): investment cost, (b) total unit cost. All costs in 2012 prices

\subsection{Biodrying and incineration facilities}

Currently, there are 2 operating biodrying facilities in Greece (Crete, Kefallonia) that produce a lowmoisture semi-stabilized end product $(<20 \%$ moisture content) that ends up to the landfill. Three additional biodrying facilities and one incineration (waste to energy) facility are planned to be constructed. Figure 3 shows the cost data of these facilities. The regression equations of Figure $3 a$ and $3 \mathrm{~b}$ are based only on the biodrying facilities. The TSPN equation, which had been derived for incineration facilities only, adequately estimates the investment cost of the sole incineration facility planned for Greece (red square). Operating data were not available for 2 biodrying facilities. The total cost from 3 biodrying facilities is depicted in Figure 3, yet the resulting regression equation is not statistically significant at $p<0.95$. According to Figure $3 b$, the total cost of the biodrying facilities ranged from $€ 48 / \mathrm{t}$ to $€ 138 / \mathrm{t}$ from which $€ 31 / \mathrm{t}$ to $€ 109 / \mathrm{t}$ comprised the operating cost. The total cost of the incineration facility was $€ 115 / t$, whilst only the operating cost of the planned WTE facility is expected to be $€ 73 / \mathrm{t}$. 
(a)

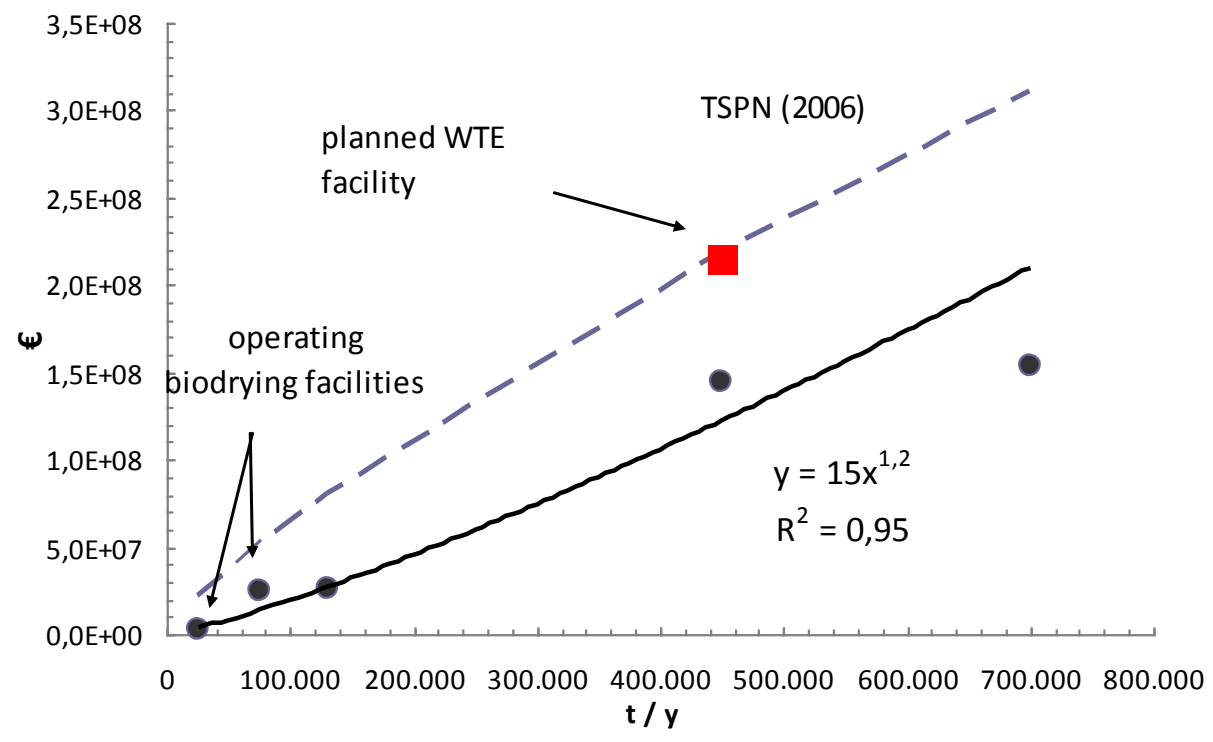

(b)

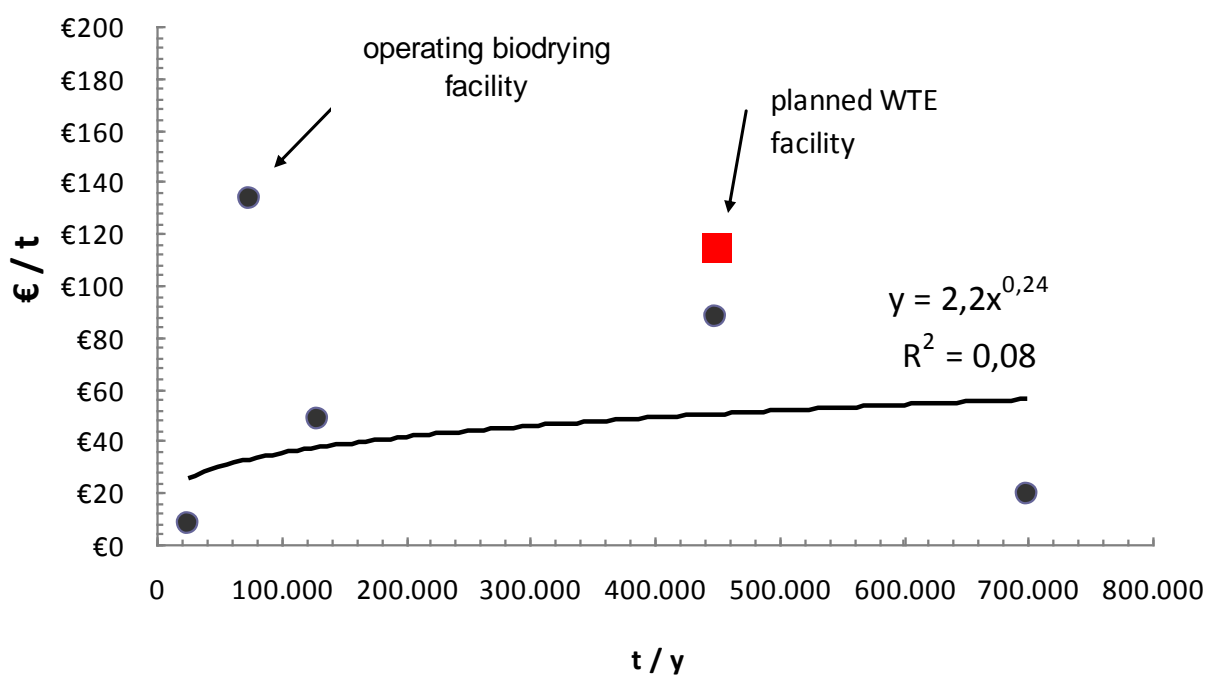

Figure 3. Cost functions for biodrying and incineration facilities in Greece, (a): investment cost, (b) total unit cost. All costs in 2012 prices

\subsection{Aerobic MBT facilities}

The cost functions for the operating and planned aerobic MBT facilities in Greece are shown in Figure 4. According to Figure 4a, a good agreement with the TSPN equations is found for aerobic MBT facilities with inlet rates less than 100,000 t/y. No economy of scale for the aerobic MBT facilities in Greece is, however, apparent, since as the size of the facility increases, the total unit cost of incoming MSW increases too. This is attributed to the high operating cost of the two largest MBT facilities used in the study. The total cost ranges from $€ 37 / \mathrm{t}$ to $€ 66 / \mathrm{t}$ for facilities with inlet rates less than or equal to $100,000 \mathrm{t} / \mathrm{y}$. However, for the 2 large facilities in Attica (inlet rates: 220,000 and 400,000 t/y), the total cost increases up to $€ 93 / t$ and $€ 162 / t$, respectively. 
(a)

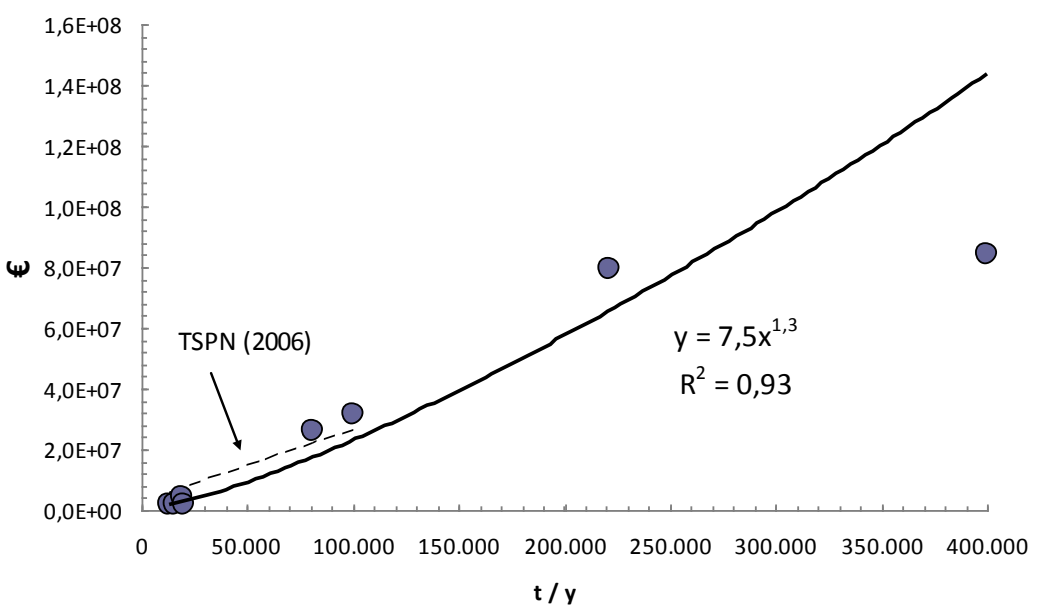

(b)

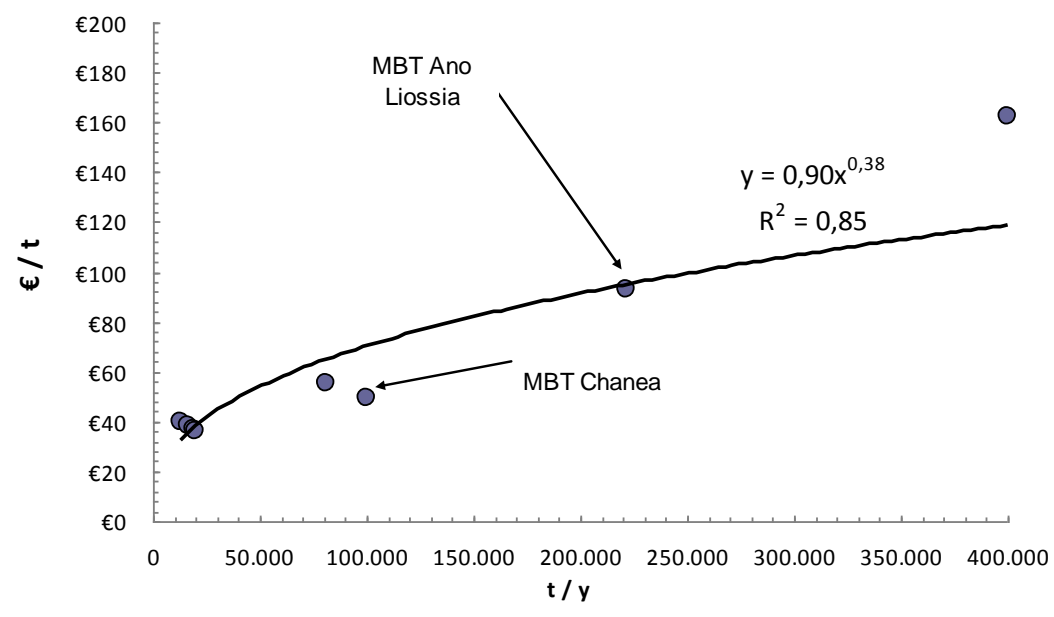

Figure 4. Cost functions for the aerobic MBT facilities in Greece;

(a) investment cost, (b) total unit cost. All costs in 2012 values.

\subsection{Material recycling facilities (MRFs)}

There are approximately 35 operating material recycling facilities (MRFs) in Greece. These facilities accept source separated dry recyclables (mainly packaging material), such as cardboard, metals, glass, other types of paper, several types of plastics and tetrapack packaging. They usually separate the incoming materials to around 10 sub-categories, which are then baled and sold to recycling companies for further processing. According to unpublished data, the rejected material from these MRFs ranges from $20 \%$ to $30 \%$ by weight of the incoming stream. This relatively high value is indicative of the poor quality of source separated materials in Greece, since a lot of residual wastes are apparently discarded in the same bins used for dry recyclables. In this work, there were available investment and operating costs for 23 existing MRFs. The investment costs included all additions made within the facility till the end of 2012. The inlet tonnages into the MRFs are those of year 2012. The operating costs include mainly maintenance costs and in most cases personnel cost; however, for some MRFs, personnel, fuel and electricity cost data were not available.

Figure 5 presents the cost data for the 23 MRFs. According to Figure $5 b$, the total unit costs for the MRFs ranged from $€ 5 / t$ to $€ 71 / t$ with an average unit cost equal to $€ 32 / t$. The economy of scale is not very distinct for the MRFs. 
(a)

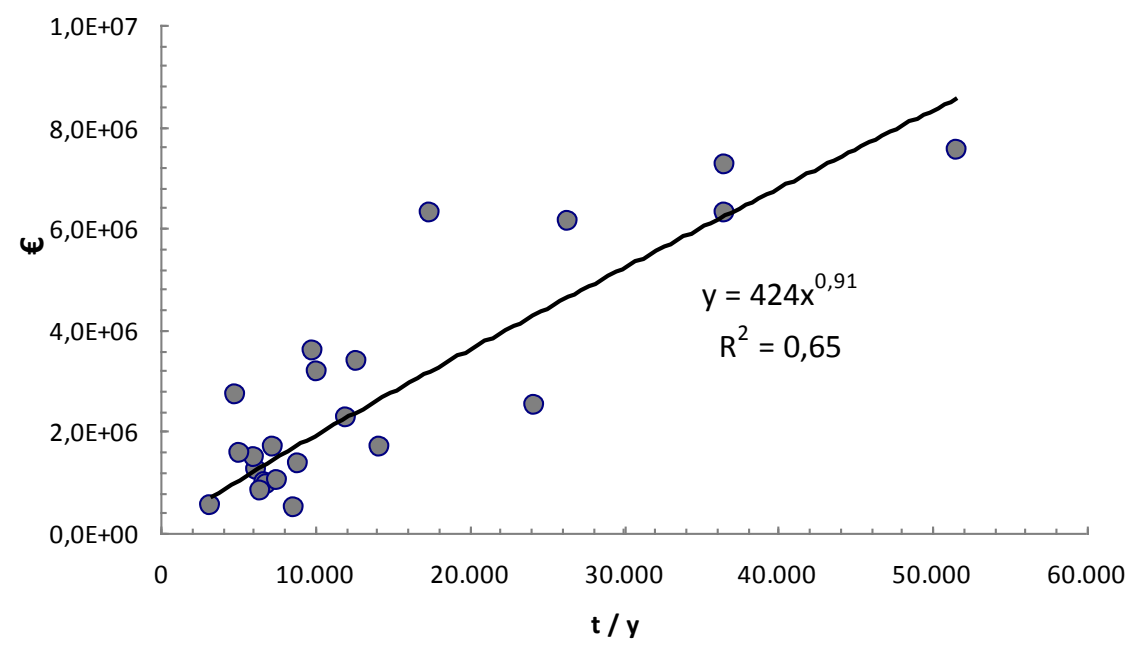

(b)

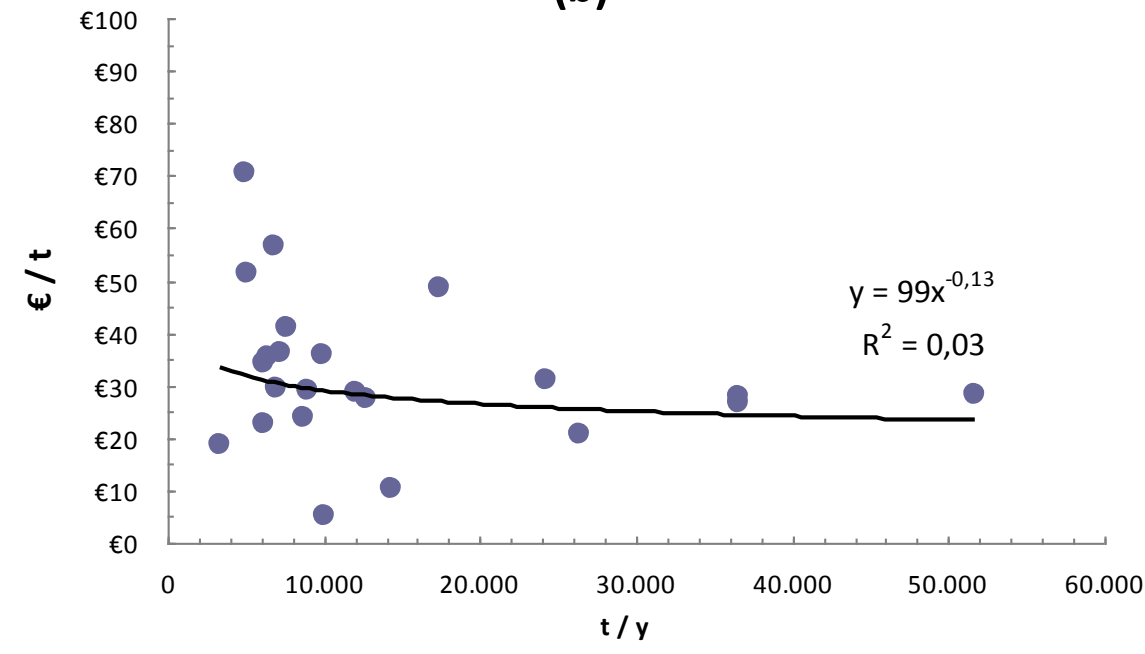

Figure 5. Cost functions for 23 existing Material Recovery Facilities in Greece (a) investment cost, (b) total unit cost. All costs in 2012 values

\subsection{Waste transfer stations}

Investment costs were available for 18 WTS in Greece ( 2 operating since 2008 and 16 constructed on 2012). No operating data were available for any of the WTS. According to Figure $6 a$, there seems to be three outliers. Figure $6 \mathrm{~b}$ depicts only the depreciated investment cost. According to Figure $6 \mathrm{~b}$, a clear economy of scale exists. The depreciated IC for WTS is less than $€ 5.5 / t$ in most cases, except for one insular WTS (€28/t) with a low waste input rate $(884 \mathrm{t} / \mathrm{y})$. Actually, the depreciated ICs recorded for WTS with inlet rates above $30,000 \mathrm{t} / \mathrm{y}$ are less than $€ 1 / \mathrm{t}$. It is also noted that the IC for WTS does not include the cost of the containers and the tractors; it solely includes the cost of the hopper, the weighing station and the paving of the site.

The depreciated unit investment costs shown in Figure $6 \mathrm{~b}$ are comparable to the cost figures presented in Komilis (2008) for 8 WTS in Western Macedonia. Komilis (2008) had recorded a range of depreciated investment costs from $€ 2 / \mathrm{t}$ to $€ 7 / \mathrm{t}$ (after conversion to 2012 prices). 
(a)

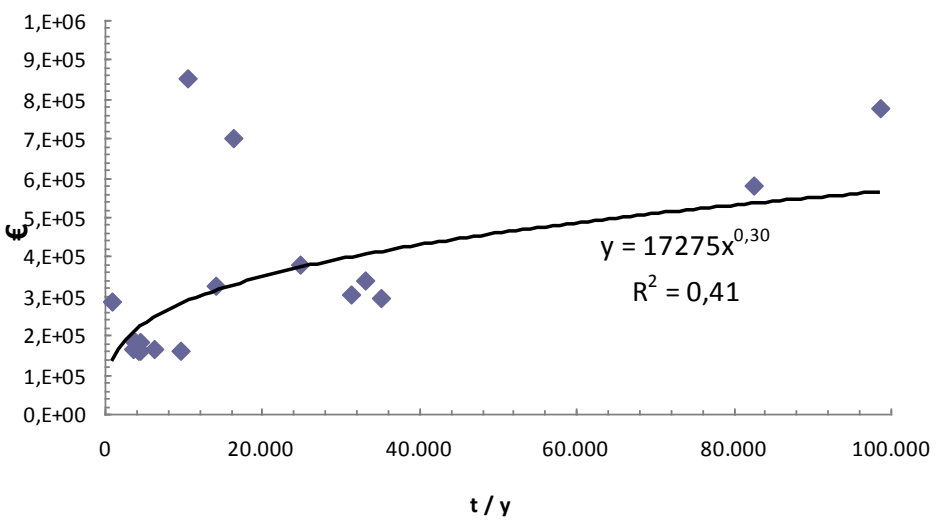

(b)

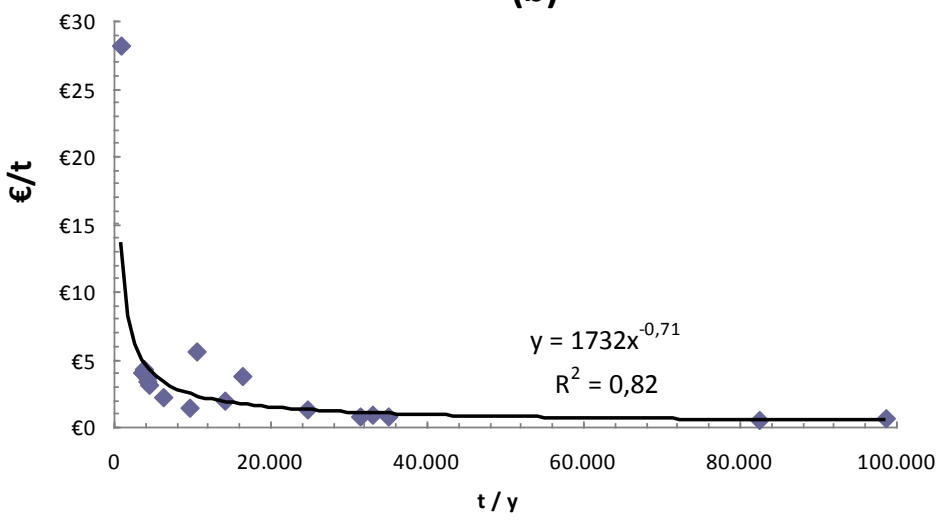

Figure 6. Cost functions for 18 Waste Transfer Stations in Greece; (a) investment cost, (b) depreciated investment unit cost. All costs in 2012 values.

\section{Conclusions}

The conclusions of this work are:

An economy of scale is observed for the sanitary landfills and the WTS in Greece. An average total unit cost for sanitary landfills in Greece is €45/t. The depreciated investment cost of 18 WTS in Greece ranges from $€ 0.5 / \mathrm{t}$ to $€ 28 / \mathrm{t}$.

No economy of scale is observed for the aerobic MBT facilities, whilst there are few data to conclude whether an economy of scale exists for the MSW anaerobic and biodrying facilities. The average total unit cost for the MRFs is $€ 32 / \mathrm{t}$.

\section{References}

Arcadis and Eunomia (2009). Assessment of the options to improve the management of bio-waste in the European Union. Annex A: Baseline Scenarios, Technical Report submitted to European Commission DG Environment. Available from http://ec.europa.eu (accessed Jan 2014).

Komilis D. (2008), Conceptual models to optimize the haul and transfer of municipal solid waste, Waste Management, 28, 2355 - 2365.

Tsilemou K. and Panagiotakopoulos D. (2006), Approximate cost functions for solid waste treatment facilities, Waste Management and Research, 24, 310 - 322.

USEPA (1997), Full cost accounting for municipal solid waste management: A handbook, Solid Waste and Emergency Response, EPA-530-R-95-041. 